\title{
Residência Criativa: tradução de poemas de Hilda Hilst na Casa do Sol
}

Dinaura M. Julles

\begin{abstract}
Resumo: Em uma residência criativa na Casa do Sol - Instituto Hilda Hilst, em Campinas - SP, foram traduzidos os dois primeiros livros do conjunto chamado "Do Desejo": o primeiro, homônimo do conjunto, e o segundo, "Da noite", constantes do livro publicado pela Editora Globo em 2001. São detalhadas algumas escolhas entre as possibilidades de vocabulário e os critérios que as nortearam, a opção pela manutenção da forma, considerando a ligação intrínseca entre os dois poemas. Por limitação de espaço, apenas a tradução de "Do Desejo" é apresentada nesta publicação. O fato de fazer a tradução na casa de Hilda Hilst, no ambiente em que ela vivia, entre os seus objetos preservados, exerceu influência significativa no resultado dos poemas traduzidos.
\end{abstract}

Palavras chave: Hilda Hilst, tradução, residência criativa.

Em um país como o Brasil, em que a poesia nem sempre conta com a devida valorização e divulgação, foi uma surpresa descobrir que o Instituto Hilda Hilst oferece residências criativas para tradução na Casa do Sol, em Campinas, São Paulo, entre outras oportunidades. Ao visitar o site http://www.hildahilst.com. $\underline{\mathrm{br} /}$, minha intenção era apenas verificar as novidades em publicações da poetisa que admiro desde a juventude.

A segunda foi receber um email com a aceitação do projeto de tradução dos dois primeiros livros do conjunto chamado "Do Desejo": o primeiro, homônimo do conjunto, e o segundo, "Da noite".

A ideia inicial era traduzir apenas "Do Desejo", mas os dois livros estão intrinsecamente vinculados pela conformação e pela temática dos poemas. "Da noite" espelha a estrutura de "Do desejo", já que ambos são compostos em 10 cantos, mas nesse espelhamento encontra-se a ampliação do significado, já que 
a "noite" citada no canto $\mathrm{V}$ - bem no meio - do primeiro livro desdobra-se no título e tema do segundo livro.

Pela relevância, pela originalidade e transgressão que os livros representam, acreditei que eles mereciam mais do que se desdobrar. Mereciam ecoar na língua inglesa.

Com uma mala para alguns dias e comida vegetariana a tiracolo, parti, em janeiro do ano passado, para a Casa do Sol, construída pela poetisa em 1975 e tombada pelo patrimônio histórico em 2011. Localizada em uma área de dez mil metros quadrados entre jardins e quintal, a Casa é mantida pelo Instituto Hilda Hilst. Um paraíso bucólico em meio a um bairro residencial razoavelmente afastado da cidade de Campinas.

A terceira surpresa foi a recepção gentil e calorosa de Olga Bilenki, pintora, uma das coordenadoras de projetos de artes visuais e administradora da Casa do Sol. E o mais importante: amiga de Hilda Hilst e residente de longa data na Casa, conhecedora da pessoa, da obra, das histórias, da residência e do complexo universo da poetisa.

$\mathrm{Na}$ chegada, fui recebida com um almoço saboroso e apresentada à Casa do Sol. Os dormitórios destinados aos residentes estavam sendo preparados para uma reforma, e por isso eu ficaria alojada na residência principal.

Um dos pressupostos da residência é participar da rotina da casa, residir de fato, não ser um hóspede. Assim, havia o compromisso de comportar-se como um dos habitantes, assumir as pequenas tarefas de cuidados com a casa e pertences pessoais, mas nenhuma rotina estabelecida.

Dediquei a maior parte do tempo à pesquisa e ao exercício de tradução propriamente ditas, entremeadas por visitas a outros locais da Casa e passeios pelo quintal e jardim. Os cômodos, a biblioteca, o escritório e os objetos de Hilda Hilst e da Casa do Sol estavam abertos e acessíveis, em uma atmosfera de liberdade e confiança.

Era frequente ver "materializado" algum aspecto dos poemas, como as avencas que realmente vicejam no terraço central, o jardim aqui ao lado, as máscaras e os tapetes antigos que adornam as paredes, os espelhos.

As humanas ladraduras são ecos dos latidos dos cachorros, uma das paixões de Hilda Hilst. Agora são dez cães mansos e sociáveis que moram e transitam pela Casa, mas que já foram uma centena na década 1970.

A sensação é de transitar entre a poesia no papel e os elementos da poesia que se concretizam na Casa do Sol. A impressão é que a tradução, mais do que 
verter palavras, deveria transpor essas realidades palpáveis, visíveis e audíveis para língua de chegada.

Não havia outros residentes na Casa no período em que lá estive. Havia muito tempo de silêncio e contemplação, inspiradores para o entendimento dos poemas e da própria Casa, que foi concebida por Hilda Hilst para ser um espaço de residência, criação e inspiração artística e hospedou diversos escritores e artistas durante vários anos.

Olga Bilenki descreveu, em proveitosas conversas, durante as refeições ou enquanto ela pintava no pátio central da Casa, a efervescência dessa época de residência, da convivência com Hilda Hilst, do casamento como escultor Dante Casarini, da amizade da vida toda com Jose Luis Mora Fuentes, idealizador do Instituto Hilda Hilst. Foram relatos esclarecedores para a percepção de como esse acervo de vivências da poetisa alimentaram sua obra, que, além da poesia dedicou-se à ficção e à dramaturgia.

Esse quadro mais amplo, visto "por alguém de dentro", foi inspirador para a tarefa de traduzir os poemas, "Do Desejo" e "Da Noite". Nesta publicação, por limitação de espaço, apenas "Desire" está sendo apresentado e comentado.

DO DESEJO

(Hilda Hilst)

Porque há desejo em mim, é tudo cintilância.

Antes, o cotidiano era um pensar alturas

Buscando Aquele Outro decantado

Surdo à minha humana ladradura.

Visgo e suor, pois nunca se faziam.

Hoje, de carne e osso, laborioso, lascivo

Tomas-me o corpo. E que descanso me dás

Depois das lidas. Sonhei penhascos

Quando havia o jardim aqui ao lado.

Pensei subidas onde não havia rastros.

Extasiada, fodo contigo

Ao invés de ganir diante do Nada.
DESIRE

(translated by Dinaura M. Julles)

I

As there is desire within me, everything is sparkle.

Before, daily life was thinking heights

Searching for That Decanted Other

Deaf to my human barking.

Gum and sweat, they were never made.

Today, in flesh and blood, laborious, lascivious

You take my body. And what repose you give me

After the chores. I dreamed of cliffs

When there was a garden by my side.

I thought of slopes where there were no paths.

Enraptured, I fuck you

Instead of howling before the Nothingness. 
Ver-te. Tocar-te. Que fulgor de máscaras.

Que desenhos e rictus na tua cara

Como os frisos veementes de tapetes antigos.

Que sombrio te tornas se repito

O sinuoso caminho que persigo: um desejo

Sem dono, um adorar-te vívido mas livre.

E que escuro me faço se abocanhas de mim

Palavras e resíduos. Me vêm fomes

Agonias de grandes espessuras, embaçadas luas

Facas, tempestade. Ver-te. Tocar-te.

Cordura.

Crueldade.

III

Colada à tua boca a minha desordem.

$\mathrm{O}$ meu vasto querer.

O incompossível se fazendo ordem.

Colada à tua boca, mas descomedida

Árdua

Construtor de ilusões examino-te sôfrega

Como se fosses morrer colado à minha boca

Como se fosse nascer

E tu fosses o dia magnânimo

E te sorvo extremada à luz do amanhecer.

IV

Se eu disser que vi um pássaro

Sobre o teu sexo, deverias crer?

E se não for verdade, em nada mudará o Universo.

Se eu disser que o desejo é Eternidade

Porque o instante arde interminável

Deverias crer? E se não for verdade
See you. Touch you. What a fulgor of masks.

What drawings and rictus on your face

Like the vehement borders of old rugs.

How shadowy you become if I repeat

The sinuous path that I pursue: a desire

Without owner, adoring you lively but freely.

And how dark I become if you bite off from me

Words and wastes. They come to me: hungers,

Thick agonies, blurred moons

Knives, storms. To see you. To touch you.

Caution.

Cruelty.
Glued to your mouth my disorder.

My vast wish.

The incompossible making itself order.

Glued to your mouth, but immoderate

Arduous

Builder of illusions, I voraciously examine you

As if you were going to die glued to my mouth

As if to be borne you might

And you were the magnanimous day

And I sip you to extremes in the dawn light.
If I say that I saw a bird

On your sex, should you believe?

If it is not true, nothing will change in the Universe.

If I say that desire is Eternity

Because the instant burns interminable

Should you believe? And if it is not reality 
Tantos o disseram que talvez possa ser.

No desejo nos vêm sofomanias, adornos

Impudência, pejo. E agora digo que há um pássaro

Voando sobre o Tejo. Por que não posso

Pontilhar de inocência e poesia

Ossos, sangue, carne, o agora

E tudo isso em nós que se fará disforme?

V

Existe a noite, e existe o breu.

Noite é o velado coração de Deus

Esse que por pudor não mais procuro.

Breu é quando tu te afastas ou dizes

Que viajas, e um sol de gelo

Petrifica-me a cara e desobriga-me

De fidelidade e de conjura. O desejo

Este da carne, a mim não me faz medo.

Assim como me veio, também não me avassala.

Sabes por quê ? Lutei com Aquele.

E dele também não fui lacaia.

Aquele Outro não via minha muita amplidão.

Nada LHE bastava. Nem ígneas cantigas.

E agora vã, te pareço soberba, magnífica

$\mathrm{E}$ fodes como quem morre a última conquista

$\mathrm{E}$ ardes como desejei arder de santidade.

(E há luz na tua carne e tu palpitas.)

Ah, por que me vejo vasta e inflexível

Desejando em desejo vizinhante

De uma Fome irada e obsessiva?
So many have said this that it may be so.

In desire come sophomanias, adornments

Impudence, temerity. And now I say there is a bird

Flying over the Tagus. Why can't I

Sprinkle with innocence and poetry

Bones, blood, flesh, the now

And all this that will become deformed on us?

V

There is the night, and there is the pitch black.

Night is the hidden heart of God

The one that for shyness I don't seek anymore.

Pitch black is when you go away or say

That you will travel, and a sun of ice

Petrifies my face and releases me

From loyalty and adjuration. Desire,

This of flesh, does not scare me.

As it came to me, it does not vassalize me.

Do you know why? I fought with That One.

And I did not become his servant.

VI

That Other did not see my great breadth.

Nothing sufficed HIM. Not even igneous songs.

And now vain, to you I look splendid, magnificent

And you fuck as the one who dies the last conquest

And you burn as I wanted to burn in holiness.

(And there is light is in your flesh and you pulse.)

Ah, why do I see me vast and inflexible

Desiring in a neighboring desire

Of an enraged obsessive Hunger? 
VII

Lembra-te que há um querer doloroso

E de fastio a que chamam de amor.

E outro de tulipas e de espelhos

Licencioso, indigno, a que chamam desejo.

Não caminhar um descaminho, um arrastar-se

Em direção aos ventos, aos açoites

E um único extraordinário turbilhão.

Por que me queres sempre nos espelhos

Naquele descaminhar, no pó dos impossíveis

Se só me quero viva nas tuas veias?

VIII

Se te ausentas há paredes em mim.

Friez de ruas duras

E um desvanecimento trêmulo de avencas.

Então me amas ? te pões a perguntar.

E eu repito que há paredes, friez

Há molimentos, e nem por isso há chama.

DESEJO é um Todo lustroso de carícias.

Uma boca sem forma, um Caracol de Fogo.

DESEJO é uma palavra com a vivez do sangue

E outra com a ferocidade de Um só Amante.

DESEJO é o Outro. Voragem que me habita.

IX

E por que haverias de querer minha alma

$\mathrm{Na}$ tua cama?

Disse palavras líquidas, deleitosas, ásperas

Obscenas, porque era assim que gostávamos.

Mas não menti gozo prazer lascívia

Nem omiti que a alma está além, buscando
VII

Remember that there is a painful wish

And ennui that is called love.

And another one of tulips and mirrors

Licentious, unworthy, called desire.

Not going astray, and dragging

Towards the winds, the lashes

And only one extraordinary whirlpool.

Why do you always want me in the mirrors

In that straying, in the dust of impossibilities

If I just want to be alive in your veins?

VIII

If you are absent there are walls in me.

Chill of stiff streets

And a trembling vanishing of the maidenhair.

So you do love me? you ask.

And I repeat that there are walls, chill

There are endeavors, yet there is no flame.

DESIRE is a lustrous Whole of caresses.

A shapeless mouth, a Fire Spiral.

DESIRE is a word with the liveliness of blood

And another one with the ferocity of only One Lover.

DESIRE is the Other. A vortex that inhabits me.
IX

And why would you want my soul

In your bed?

Liquid, delightful, harsh, obscene words

Were said, because that was how we liked.

But I didn't lie climax pleasure lust

Nor omitted that the soul is beyond, seeking 
Aquele Outro. E te repito: por que haverias

De querer minha alma na tua cama?

Jubila-te da memória de coitos e de acertos.

Ou tentame de novo. Obriga-me.

X

Pulsas como se fossem de carne as borboletas.

E o que vem a ser isso? perguntas.

Digo que assim há de começar o meu poema.

Então te queixas que nunca estou contigo

Que de improviso lanço versos ao ar

Ou falo de pinheiros escoceses, aqueles

Que apetecia a Talleyand cuidar.

Ou ainda quando grito ou desfaleço

Adivinhas sorrisos, códigos, conluios

Dizes que os deve ter nos meus avessos.

Pois pode ser.

Para pensar o Outro, eu deliro ou versejo.

Pensá-lo é gozo. Então não sabes?

INCORPÓREO

É O DESEJO.
That Other. And I repeat: why would you

Want my soul in your bed?

Rejoice at the memory of intercourses and hits.

Or tempt me again. Oblige me.

$\mathrm{X}$

You pulse as if the butterflies were of flesh.

And what is this about? you ask.

I tell you that this is how my poem should start.

Then you complain that I am never with you

That improvising I throw verses in the air

Or that I talk about scots pines, those

Talleyrand enjoyed taking care of.

Or even when I cry or faint

You guess smiles, codes, collusions

You say I probably have them in my reverses.

It is possible.

To think the Other, I hallucinate or versify.

To think of him is a climax. Don't you know?

UNBODIED

IS DESIRE.

\section{Comentários às traduções de Do Desejo (Desire)}

Segundo Mario Laranjeira (2003, p. 15), “etimologicamente, traduzir (do latim trans + ducere) significa levar através de. Ora, o verbo levar (duco) é essencialmente transitivo; portanto, a primeira pergunta a responder é: O que se leva? Informação? Emoção? Imagem?” Depende do que será traduzido. Como Victor Hugo afirma (2003, p. 46) que a poesia "é aquilo que existe de íntimo em tudo", a tradução de poesia é levar a intimidade do trabalho do poeta ao leitor.

Talvez ninguém tenha tratado melhor da própria intimidade na forma intimista da poesia do que Hilda Hilst. A tradução da sua poesia consiste em desnudar o original em língua portuguesa para o leitor de língua inglesa, levando até ele as informações, as emoções e as imagens de Do Desejo. 
Disse Pound, citado por Mário Laranjeira à página 118 de Poética da Tradução: "Penso que existe um conteúdo "fluido", assim como um conteúdo "sólido"; que certos poemas podem ter uma forma, tal como as árvores a têm, enquanto a de outros seria como a da água despejada num vaso". Os poemas de Hilda Hilst têm tanto a solidez das árvores, na forma e estrutura, quanto a fluidez das águas que ela mesma cita em seus versos. Assim, como foram mantidas a estruturas em dez cantos do poema, a atenção foi para a escolha do vocabulário que levaria Do Desejo até Desire com a aproximação possível à sofisticação da linguagem do original.

\section{Do Desejo}

No canto I, "visgo", segundo o Dicionário Informal “ é uma substância retirada de uma árvore que levada ao fogo e obtento temperatura alta torna-se um material pastoso e pegante; os índios caçavam pássaros com esse material", e significa também um arbusto que possui uma resina viscosa (chamaecrista hispidula), que não será considerado neste caso. Assim, no sentido da substância, as possibilidades eram birdlime ou bird lime (substância adesiva usada para caçar pássaros) e gum (substância pegajosa encontrada nos troncos de algumas árvores), escolhida pela concisão.

No canto II, para "rictus", que significa expressão em forma de sorriso que aparece em cadáveres; boca semiaberta, o dicionário Merriam-Webster registra a mesma palavra: "rictus": New Latin, from Latin: open mouth, from ringi: to open the mouth. Como a palavra latina tem o mesmo significado dicionarizado em Português e Inglês, sua manutenção pareceu a melhor opção, em respeito à escolha da autora.

No mesmo canto, "vívido mas livre", sequência de dois adjetivos, teve o paralelismo rompido na tradução "lively but freely", na qual o adjetivo é seguido por advérbio, para melhor sonoridade, já que "as agramaticalidades são um indício visível de que o texto deve ser entendido em outro nível.” (2003, p. 85).

Ainda no canto II, "cordura" e significa prudência, sensatez, e cujas possibilidades para tradução eram "prudence; caution; mindfulness", foi traduzida como "caution", para manutenção da sonoridade das consoantes velares de cordura/ crueldade e caution/cruelty.

Para o "incompossível" do canto III, verbete ainda não incluído nos dicionários de Português do Brasil, está assim definido no http://dicionarioportugues. org/pt/incompossivel: "A definição de incompossível no dicionário de Português é pouco usual. Que não pode ser compatível; que não entra em acordo 
com; inconciliável", há "incompossible" no Oxford Philosophy Dictionary, com significado de "mutually exclusive", e no Webster's, definido como "Not capable of joint existence; incompatible; inconsistent". A semelhança da sonoridade e o mesmo número de sílabas do vocábulo original favoreceram a escolha.

Não são numerosas, e, portanto, são relevantes, as ocorrências de rimas nestes poemas de Hilda Hilst, como no oitavo e décimo versos deste canto: "como se fosse nascer... à luz do amanhecer". Para refleti-la, a opção foi por uma agramaticalidade, i.e., deslocar o auxiliar "might" para o final do verso: "As if to be born you might', in the dawn light."

Aparentes desafios no canto IV, como "sofomania", mania de se passar por sábio, encontram soluções bastante próximas como "sophomania", com o mesmo sentido, "unrealistic belief in one's own intelligence; delusion of superintelligence", verificado em dictionary.com. Desafio real é a rima pejo/Tejo. Diante da impossibilidade de reproduzi-la, a opção foi inverter a sequencia "Impudência, pejo" para "Modesty, temerity (respectivamente "unwillingness to show your body or do anything that may attract sexual interest", e "when someone says or does something in a way that shows a lack of respect for other people and is likely to offend them" segundo o Longman Dictionary of Contemporary English)", para ao menos recuperar o som inicial " $t$ " de temerity e Tagus.

No canto VII, "caminhar um descaminho" e "descaminhar" foram resolvidos com "going astray", no sentido de "to be lost" and "straying" to stray: to move away from the place you should be", nas definições do Longman.

O eco das "ruas duras", como canto VIII, foi solucionado com a escolha do adjetivo "stiff", entre outras possibilidades como "hard e harsh", aproveitando a sonoridade das sibilantes em stiff e street.

As opções para tradução de "molimento" (dativo. $2^{a}$ declinação do Latim - molimentum ) foram encontradas diretamente no (dicionário Latin/English Glosbe) $=$ effort, exertion, endeavour, labor. Ao verificar as definições de cada uma em dicionários monolíngues, o termo escolhido foi "endeavor": American English formal: an attempt to do something new or difficult (segundo o Longman), em virtude da intenção de manter o registro mais alto.

O mesmo verso termina com o substantivo "chama". Bem simples, com diversas alternativas, como "flame; blaze, fire; light; (fig.) ardour, passion", foi traduzido como flame, por estar definido como "literary: a strong feeling:", de acordo com o Longman, e fazer parte de colocados como flame of anger/desire/passion etc.

Observadas essas questões pontuais de escolha de vocabulário, foi preciso lembrar que "se é o poema todo que constitui a unidade de significância, também 
98

Dinaura M. Julles. Residência Criativa: tradução de poemas de Hilda Hilst na Casa do Sol

será o poema toda a unidade de tradução poética (2003, pág. 84). Assim, terminada a tradução, foi preciso voltar à primeira linha do primeiro canto do primeiro poema e rever tudo do ponto de vista da unicidade, o que exigiu diversos ajustes às tentativas iniciais e resultou nesta tradução.

Por ter sido feito na Casa do Sol, residência de Hilda Hilst, este exercício foi mais do que uma atividade intelectual. Foi um profundo mergulho. Mergulho nos quadros de Olga Bilenky, pintora e inspirada anfitriã; no universo da poetisa com os cachorros, altares, livros, nesse mundo meio terra e meio magia, em que habitam desde as avencas de Do Desejo até figueira ancestrais.

O erotismo "Do Desejo" está nas sutilezas dos detalhes da Casa do Sol, nos reflexos dos espelhos, nos olhares vivos das fotografias, nos movimentos implícitos das mandalas. Mais que uma residência, uma profunda experiência. A tradução dos poemas, objetivo principal, acabou sendo uma consequência. Que ela ecoe e reverbere em outras línguas e "que venham a enriquecer a cultura onde passam a conviver com todos os outros nela existentes". (2003; pág. 147).

Sinauram. fulles 


\section{Referências}

HILST, Hilda. Do Desejo. São Paulo: Globo, 2007.

LARANJEIRA, Mauro. Poética da Tradução. São Paulo: Edusp/Fapesp, 2003.

\section{Dicionários}

Longman Dictionary of Contemporary English

Logman Dictionary of English Language and Culture

\section{Dicionários Online}

$\underline{\text { www.dicionarioinformal.com.br }}$

www.merriam-webster.com

http://dicionarioportugues.org

dictionary.com 
Fotos: Cenas da Casa do Sol - Instituto Hilda Hilst - Campinas - SP
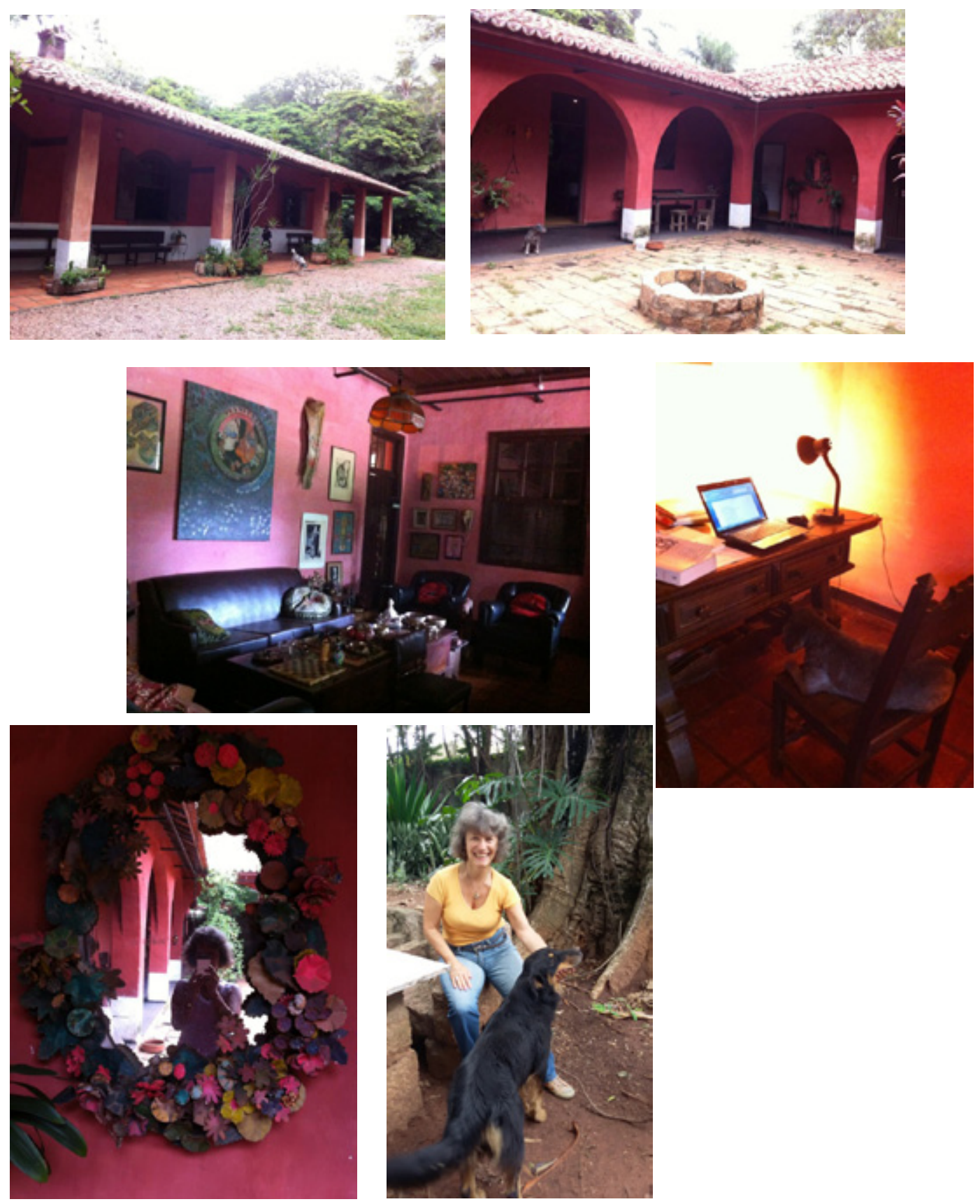


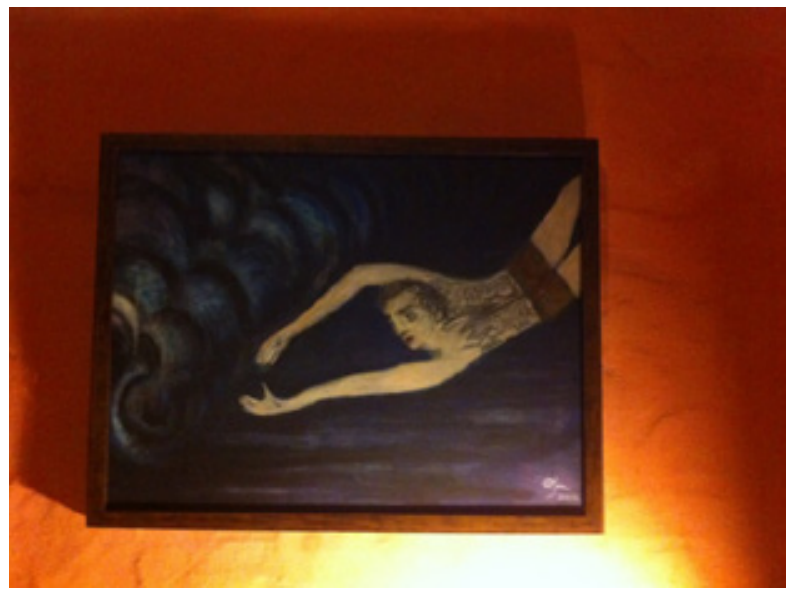

[quadro O Mergulho, de Olga Bilenki]

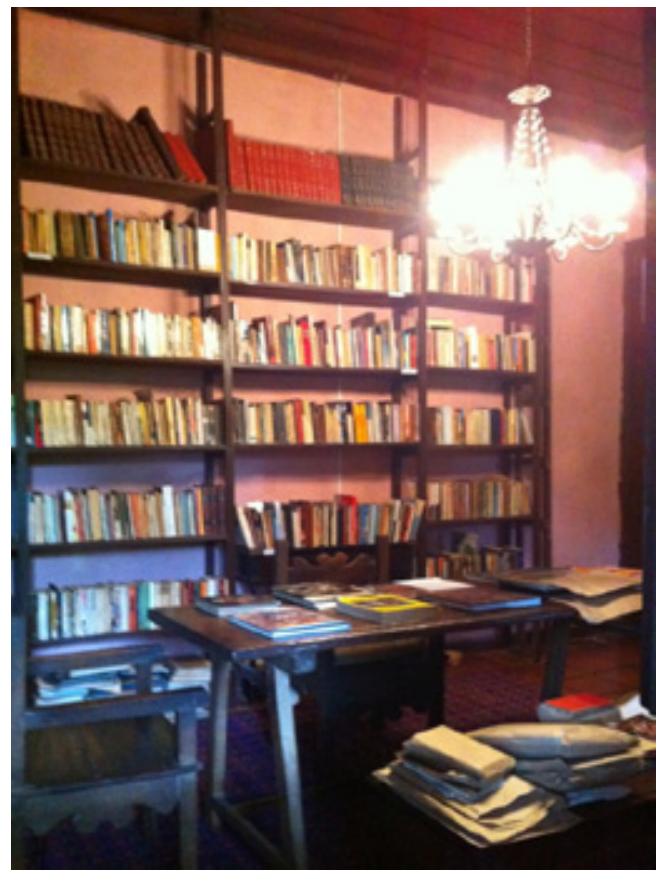

[biblioteca da Hilda Hilst] 